\title{
Estimate the geomorphological parameters of the Arang watershed in Chhattisgarh region
}

\section{GEETA AND ANISA}

Received : 14.02.2017; Revised : 09.03.2017; Accepted : 19.03.2017

See end of the Paper for authors' affiliation

Correspondence to :

\section{ANISA}

Department of Farm Machinery and Power Engineering, Vaugh School of Agricultural Engineering and Technology, Sam Higginbottom Institute of Agriculture, ALLAHABAD (U.P.) INDIA

Email : anisa0987@ gmail.com
- ABSTRACT : This study was conducted for the Arang watershed of the Chhattisgarh, India. Several geomorphological parameters of the watershed were determined using standard procedure. The Arang is $3^{\text {rd }}$ order watershed and comprises of 10 villages. Predominant soil of the watershed is clay loam. The watershed receives an average annual rainfall of $1400 \mathrm{~mm}$, out of which the monsoon season (June to October) contributes more than 85 per cent rainfall. The number of $1^{\text {st }}, 2^{\text {nd }}$ and $3^{\text {rd }}$ Order were found to be 20,4, 1 , respectively. The different geomorphometric parameters of watershed were determined and result showed that total length of stream segments were 26.14, $9.37,8.56 \mathrm{~km}$, respectively. Area of sub-basin for $1^{\text {st }}, 2^{\text {nd }}$ and $3^{\text {rd }}$ order streams and of different order streams were to be $32.35,43.94$, and $54.50 \mathrm{~km}^{2}$, respectively, for $1^{\text {st }}, 2^{\text {nd }}$ and $3^{\text {rd }}$ order streams. The mean bifurcation ratio for the watershed was found to be 4.64 . The length ratio, circularity ratio and elongation ratio for the Arang watershed were determined and found to be 2.724, 0.9148 and 0.973 , respectively. The hypsometric integral of the watershed was calculated to be $0.998 \mathrm{~km}$. The drainage density, length of over land flow and constant of channel maintenance of the watershed were found to be $0.808 \mathrm{~km} / \mathrm{km}^{2}, 0.618 \mathrm{~km}$ and $1.237 \mathrm{~km}$, respectively. The main channel slope of the watershed was 0.005 whereas compactness co-efficient of the watershed was 1.093 . The stream frequency, basin shape factor, form factor, and ruggedness number of the watershed were 0.458 $\mathrm{km}^{2}, 2.578,0.387,0701$ and 0.016 , respectively. The values of relative relief and relative ratio of the watershed was found to be $1.452 \times 10^{-3}$ and $1.687 \times 10^{-3}$, respectively. The weighted average slope of the entire watershed was found to be 1.5 per cent. This parameter which indicates that topography of watershed is flat.

- KEY WORDS : Morphological parameters, Geomorphological watershed parameters, Runoff measurement parameters, Geomorphological parameters, Watershed parameters, Geomorphological features

-HOW TO CITE THIS PAPER : Geeta and Anisa (2017). Estimate the geomorphological parameters of the Arang watershed in Chhattisgarh region. Internat. J. Agric. Engg., 10(1) : 109-113, DOI: 10.15740/HAS/IJAE/10.1/109-113. 